\title{
Efficiency of protected areas in Amazon and Atlantic Forest conservation: A spatio-temporal view
}

\author{
Thadeu Sobral-Souza $^{\mathrm{a}, \mathrm{b}, *}$, Maurício Humberto Vancine ${ }^{\mathrm{a}}$, Milton Cezar Ribeiro ${ }^{\mathrm{a}}$, \\ Matheus S. Lima-Ribeiro ${ }^{c}$ \\ a Bioscience Institute, UNESP - Univ Estadual Paulista, Câmpus Rio Claro, Department of Ecology, Spatial Ecology and Conservation Lab (LEEC), Av. 24-A, 1515, Bela \\ Vista, Rio Claro, São Paulo, Brazil \\ ${ }^{\mathbf{b}}$ Biological Science Course, Universidade Metropolitana de Santos, Unimes, Avenida Conselheiro Nébias, 374, Vila Nova, Santos, São Paulo, Brazil \\ ${ }^{\mathrm{c}}$ PaleoMACROecology Lab., Universidade Federal de Goiás - Regional Jataí, R. Riachuelo, 1530 - Setor Samuel Graham, Jataí, Goiás, Brazil
}

\section{A R T I C L E I N F O}

\section{Keywords:}

Climate change

Paleoclimate simulation

Conservation biology

Tropical forests

Niche modeling

\begin{abstract}
A B S T R A C T
The Amazon and Atlantic Forest are considered the world's most biodiverse biomes. Human and climate change impacts are the principal drivers of species loss in both biomes, more severely in the Atlantic Forest. In response to species loss, the main conservation action is the creation of protected areas (PAs). Current knowledge and research on the PA network's conservation efficiency is scarce, and existing studies have mainly considered a past temporal view. In this study, we tested the efficiency of the current PA network to maintain climatically stable areas (CSAs) across the Amazon and Atlantic Forest. To this, we used an ecological niche modeling approach to biome and paleoclimatic simulations. We propose three categories of conservation priority areas for both biomes, considering CSAs, PAs and intact forest remnants. The biomes vary in their respective PA networks' protection efficiency. Regarding protect CSAs, the Amazon PA network is four times more efficient than the Atlantic Forest PA network. New conservation efforts in these two forest biomes require different approaches. We discussed the conservation actions that should be taken in each biome to increase the efficiency of the PA network, considering both the creation and expansion of PAs as well as restoration programs.
\end{abstract}

\section{Introduction}

Historically, the Amazon and the Atlantic Forest were continuous. Currently, however, they are separated by a dry vegetation belt formed by the Cerrado, Chaco, Caatinga and relicts of Seasonally Dry Tropical Forests (Prado, 2000; Hoorn et al., 2010; Dryflor, 2016). The Amazon is located in the northern-northwestern portion of South America, whereas the Atlantic Forest is the predominant vegetation covering most of the continent's eastern coast (Fig. 1). These biomes have high rates of endemism, species richness and diversity, but they are both suffering from severe forest loss (Laurance et al. 2009; Ribeiro et al. 2009). The Amazon harbors approximately $60 \%$ of rainforests remaining worldwide, making it one of the most important biomes for preserving biodiversity, the water cycle and global climate (Salati and Vose, 1984; Fearnside, 1999). Expansion of agriculture and livestock, mainly in the southern and eastern regions (Morton et al. 2006; DeFries et al. 2008), has accelerated the loss of Amazon forest cover (SoaresFilho et al. 2006).

The fragmentation scenario of Atlantic Forest is even more drastic.
Approximately 100 million people (c.a. $70 \%$ of Brazilian population) live in large cities within this forest domain (Martinelli et al., 2013). Furthermore, massive industrialization and agricultural expansion have fragmented the forested area (Scarano and Ceotto, 2015). Currently, only $11.6 \%$ of its original forest cover remains (Ribeiro et al., 2009), distributed in a mosaic of small disconnected fragments (Joly et al., 2014) that often do not exceed 50 ha (Ribeiro et al., 2011). The Atlantic Forest is listed among 25 global priority conservation hotspots (Myers et al., 2000; Mittermeier et al., 2004).

Climate change is a driver of biodiversity loss (Root et al., 2003; Araújo et al., 2004; Bellard et al., 2012). It may cause spatial displacement of species ranges since species tend to shift toward environmentally suitable areas over time (Eldredge et al., 2005), as demonstrated by some Atlantic Forest tree species (Colombo and Joly, 2010). Due to this threat in a future climate scenario, the Atlantic Forest is considered as one of the three hotspots most vulnerable to global warming (Bellard et al., 2014).

The combined impacts of habitat fragmentation and climate change on Amazon and Atlantic Forest biodiversity highlight the need to

\footnotetext{
* Corresponding author. Bioscience Institute, UNESP - Univ Estadual Paulista, Câmpus Rio Claro, Department of Ecology, Spatial Ecology and Conservation Lab (LEEC), Av. 24-A, 1515, Bela Vista, Rio Claro, São Paulo, Brazil.

E-mail address: thadeusobral@gmail.com (T. Sobral-Souza).
} 


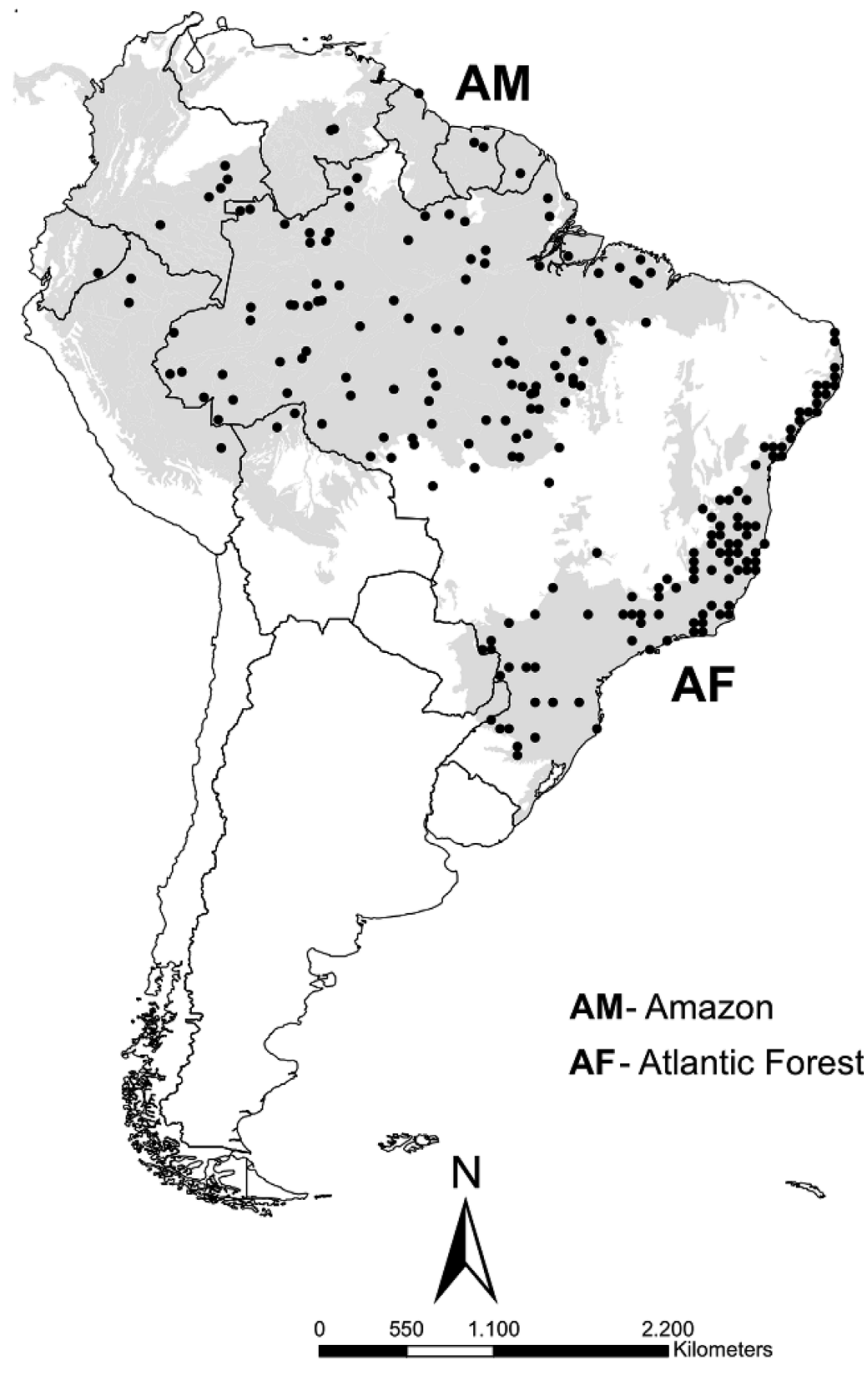

Fig. 1. Amazon and Atlantic Forest geographical delimitation (modified from Olson et al. (2001) and Lima et al. (2017), respectively) and the occurrence points used to build the ENMs.

increase conservation actions such as the creation of protected areas (PAs). However, these strategies are only marginally effective for local biodiversity conservation (Colyvan et al., 1999; Rylands and Brandon, 2005; Jenkins and Joppa, 2009). In this scenario of high rates of habitat loss, fragmentation and climate change, innovative and more effective biodiversity conservation strategies with the potential for worldwide application are needed. Approaches being discussed include the Reserve Selection method, which aims to maximize biodiversity within PAs (Margules and Pressey, 2000). However, the shift of species distribution over time could decrease the efficiency of PAs (Araújo et al., 2004). Thus, to ensure conservation efficiency and the maintenance of species over time, the design of PAs must consider a climate change scenario (Araújo et al., 2011).

The most common Reserve Selection Method uses information about species distribution and assumes that PAs should encompass areas with greater species diversity and, in some cases, long-term species persistence (Cabeza and Moilanen, 2001). However, species distribution patterns are dynamic over time, while PAs protect populations in a static space and for a limited period. These aspects increase the risk of PAs not adequately protecting endangered species in the long term if climate change results in range shifts (Araújo et al., 2002). Consequently, other methods have been developed to ensure the efficiency of PAs within climate change scenarios, such as the Habitat Suitability and Reserves Connectivity Methods (Onal and Briers, 2002; Cabeza, 2003;
Cabeza et al., 2004). These methods use a niche modeling approach to infer the dynamics of species distribution within a climate change scenario. Distribution patterns for many species are predicted for various climate scenarios, and an overlap of these distributions shows a geographical pattern of species richness. Identifying the areas with a high richness ratio in all climate scenarios ensures the most suitable placement of PAs (Araújo et al., 2004; Loyola et al., 2012).

Although various methods for predicting PA efficiency exist, the knowledge concerning Amazon and Atlantic Forest PA efficiency is limited to a few papers that tested the conservation of high richness areas under the current climate and/or future climate change. For example, studies reported a loss of phylogenetic diversity of frog species inside Atlantic Forest PAs under a global warming scenario (Lemes et al., 2014; Loyola et al., 2014). Similarly, Ferro et al. (2014) observed a loss of Arctiidae (moths) within Atlantic Forest PAs. In contrast, the Amazon PAs were shown to be effective in preserving areas with higher species richness of freshwater turtles (Fagundes et al., 2016) and mammals (Avezedo-Ramos et al., 2006) under current climate and habitat fragmentation conditions.

Another approach to testing PA efficiency is to contrast protected areas' delimitation with that of Climatically Stable Areas (CSAs). Terribile et al. (2012) proposed that PAs should be delineated to coincide with long-term CSAs, which are suitable for species occurrence in past, present and (if possible) future climate conditions. CSAs ensure the survival of different species by providing them with suitable habitats over time (Carnaval et al., 2009). CSA, in combination with the presence of large-sized seed dispersers, was important for maintain genetic diversity of Euterpe edulis, a key palm tree within Atlantic Forest biome (Carvalho et al., 2017). Therefore, PAs that cover CSAs offer species long-term protection, regardless of the species' dispersion ability and distribution shifts (Collevatti et al., 2013).

The Atlantic Forest CSAs (sometimes reported as refuges) have been proposed based on biome delimitation and for different taxa (Carnaval and Moritz, 2008; Carnaval et al., 2009; Carvalho and Del Lama, 2015). Several Amazon CSAs have also been proposed, varying according to taxonomic group (Haffer, 1969; Vanzolini and Williams, 1981; Prance, 1982; Brown, 1987; Haffer and Prance, 2001). However, there is no consensus on where these CSAs occur or on whether Amazon CSAs actually exist (Colinvaux et al., 2000; Bush and Oliveira, 2006). So far, no studies have tested the efficiency of PAs to conserve Amazon and Atlantic Forest CSAs, despite this knowledge this being of primary importance given the high rates of species richness and high intraspecific genetic variability in these areas (see Haffer, 1969; Carnaval and Moritz, 2008; Terribile et al., 2012; Collevatti et al., 2013).

In this paper, we aim to quantify the efficiency of PAs in the conservation of Amazon and Atlantic Forest CSAs. We use ecological niche modeling techniques to simulate the biomes and their paleoclimate in three different temporal climate change conditions - Last Glacial Maximum (LGM; 21ka), Holocene (6ka) and current - to propose conservation priority areas in both biomes. These Pleistocene climatic scenarios were used because it is recognized by changing in the geographical delimitation of studied biomes through time (Carnaval et al., 2009; 2009; Sobral-Souza et al. 2015a,b). Based on the difference between Atlantic Forest and Amazon fragmentation scenarios and the size of remaining forests (cited above), we hypothesize that Amazon PAs are more efficient than Atlantic Forest PAs in the conservation of CSAs.

\section{Methods}

\subsection{Inferring the potential distribution of Amazon and Atlantic Forest over} time

We used an Ecological Niche Modeling (ENM) framework to infer the current distribution and the palaeodistribution (21ka and 6ka) of the Amazon and Atlantic Forest. The ENM technique estimates the association between environmental variables (usually climate) and 
occurrence points to characterize the tolerated variation in environmental conditions and to plot potential suitability in other locations where there is no known occurrence (Franklin, 2009; Peterson et al., 2011). Although ENM is normally used to infer species distribution, this technique has also been used to predict biome delimitation and biome modeling (see Sobral-Souza et al., 2015a). To predict biome distribution over time, we selected occurrence points using a geographical filter with $0.5^{\circ}$ cell resolution based on current biome delimitations adapted from the terrestrial ecoregions proposed by Olson et al. (2001) and the extent of Atlantic Forest as described in Lima et al. (2017). To get the occurrence points, we randomized 100 points distributed over almost the entire geographical extent of each biome (100\% for Amazonia and 96\% for Atlantic Forest), including some ecotone regions (Fig. 1).

According to Clements (1949) and Whittaker (1971) climate conditions, mainly mean temperature and annual precipitation, are the major variables influencing biome delimitation worldwide. Based on this information, we used annual mean temperature and annual precipitation as variables to build the biome models used here. Several Atmosphere-Ocean Global Circulation Models (AOGCMs) that infer past global climate currently exist; we used five of them - CCSM, CNRM, IPSL, MRI and MIROC - with $0.5^{\circ}$ resolution $(\sim 50 \mathrm{~km} \times 50 \mathrm{~km}$ at Equator, available in EcoClimate database - Lima-Ribeiro et al., 2015) and the Neotropical region as background extension. We selected this extension following the historical and evolutionary background selection criteria proposed by Barve et al. (2011).

We used five algorithms to predict past and current distributions of Amazon and Atlantic Forest, including three presence-only algorithms - (1) Bioclim (Nix, 1986), (2) Mahalanobis distance (Farber and Kadmon, 2003) and (3) Domain/Gower distance (Carpenter et al., 1993) - and two presence/background algorithms: (4) support vector machines (SVM) (Tax and Duin, 2004) and (5) maximum entropy (Phillips and Dudik, 2008). We used this combination of different algorithms to increase the reliability of the predictions (see Barry and Elith, 2006; Diniz-Filho et al., 2009). All models were built based on the current climate scenario and projected to each of the past climate conditions (21ka and 6ka).

To evaluate the generated models, we randomized the occurrence points in two groups, train and test, using bootstrap analysis with $70 \%$ and $30 \%$ of the points, respectively. As these two groups are subsets of the same occurrence points, we reduced data correlation throughout a randomized bootstrap process 20 times for each algorithm and each AOGCM. Thus, we ran 500 models (20 times x 5 algorithms x 5 AOGCMs) for each temporal scenario in the Amazon and another 500 models for Atlantic Forest temporal delimitation predictions.

Subsequently, we estimated the lowest presence threshold (LPT) value (Pearson et al., 2007) for each model to transform the continuous suitability maps into binary maps (presence or absence). We then obtained the frequency map by ensemble forecasting (Araújo and New, 2007). For this, we first concatenated maps within the same algorithm, then within the same AOGCM and finally, between AOGCMs. The final suitability values varied from 0 to 500 ; i.e., each cell displayed a value corresponding to the frequency with which occurrence was predicted as presence. The final prediction for each temporal scenario was obtained using the threshold of 50\% for Amazon and $75 \%$ for Atlantic Forest. These thresholds were used because they generated maps with potential distribution areas similar to the current actual distribution.

Finally, we evaluated the models by estimating the true skill statistic (TSS) based on the LPT values. The TSS values varied from -1 to 1 . Negative or close-to-zero values indicate that the models are not statistically different from randomly generated models; values close to 1 indicate good models, but values above 0.5 are assumed to indicate suitable models (Allouche et al., 2006).

\subsection{Calculating the climatically stable areas and protected area efficiency}

To predict the Atlantic Forest and Amazon CSAs, we overlapped the maps of potential distribution for all temporal scenarios. We designated as CSA the cells that were predicted to be suitable for biome occurrence in all temporal climate scenarios. We then calculated the current biome's predicted area $\left(\mathrm{km}^{2}\right)$ and the area of its CSAs. For this purpose, we georeferenced all maps using a coordinate geographic system (Datum WGS84) and calculated the total area. Using $0.5^{\circ}$ cell resolution, the cell area was $\sim 2500 \mathrm{~km}^{2}$.

To calculate PA efficiency, we downloaded a shapefile of South American PAs, including full protection areas and sustainable use units (available on http://www.protectedplanet.net). For Amazon, we used PAs of all country that it embraced. But, for Atlantic Forest PAs we used only Brazilian PAs. After mapping all PAs, we overlapped the PA and CSA maps to obtain a map of the PAs situated within CSAs. In some cases, the area of the PA was either smaller than the cell size $\left(0.5^{\circ}\right)$, or it incorporated only portions of different cells. Therefore, we considered cells that contained any proportion of PA as protected, following Ferro et al. (2014). Next, we inferred the areas $\left(\mathrm{km}^{2}\right)$ of CSAs that are protected by PAs. Finally, to test PA efficiency, we created four indexes: (i) protection index - percentage of current biome extent that is protected by PAs; (ii) CSA index - the percentage of current biome extent that is considered as CSAs; (iii) CSA protection index - the percentage of CSAs that are protected by PAs; and (iv) efficiency index - the percentage of PAs that encompass CSAs.

\subsection{Proposing areas for conservation prioritization}

To propose an area for conservation prioritization, we first mapped unprotected CSAs. Then, we used the IFL 2013 database (available at http://www.intactforests.org/data.ifl.html) to infer which unprotected CSAs have intact forest remnants free of anthropogenic modification, considering only large and connected patches and excluding small and disconnected remnants. We assigned each of these patches to one of three conservation priority categories: very high priority area, for CSAs with unprotected intact forest remnants; high priority area, for CSAs with unprotected and fragmented forest remnants; medium priority area, for more recent climatically stable areas (6ka to current) with unprotected intact forest remnants.

\section{Results}

\subsection{Potential distribution of Amazon and Atlantic Forest over time}

The ENM predictions were reliable for all algorithms and AOGCMs, evidenced by TSS values higher than 0.5 . The models inferred a distribution of Amazon and Atlantic Forest similar to the biomes' known delimitations (0 k; Fig. 2). From 21ka to the present, the Amazon and Atlantic Forest have undergone expansion and retraction, respectively (Fig. 2, Table 1).

\subsection{Climatically stable areas and protected area efficiency}

Our results revealed three disconnected CSA blocks within the Atlantic Forest: in the north, the center, and the south respectively. The majority of Atlantic Forest CSAs are near the coast. In the Amazon, the CSAs are broad and continuous and cover most of the current biome. Most CSA patches occur in eastern region of the Amazon, while minor patches are found along its western and southern boundaries (Fig. 3).

Our index inferred higher efficiency of Amazon PAs for CSA conservation, in comparison to Atlantic Forest PAs. The Amazon protection index was $40.1 \%$, the Amazon CSA index was 58.2\%, the Amazon protection CSA index was 0.407 , and the Amazon efficiency index was $59.2 \%$. In comparison, the Atlantic Forest's protection index was $9.1 \%$ of the biome is protected; the Atlantic Forest CSA index was $22.7 \%$, the Atlantic Forest CSA protection index was $7.1 \%$, showing that larger CSAs lack protection; and the Atlantic Forest efficiency index was $17.9 \%$, i.e., most Atlantic Forest protected areas fall outside of the CSAs 

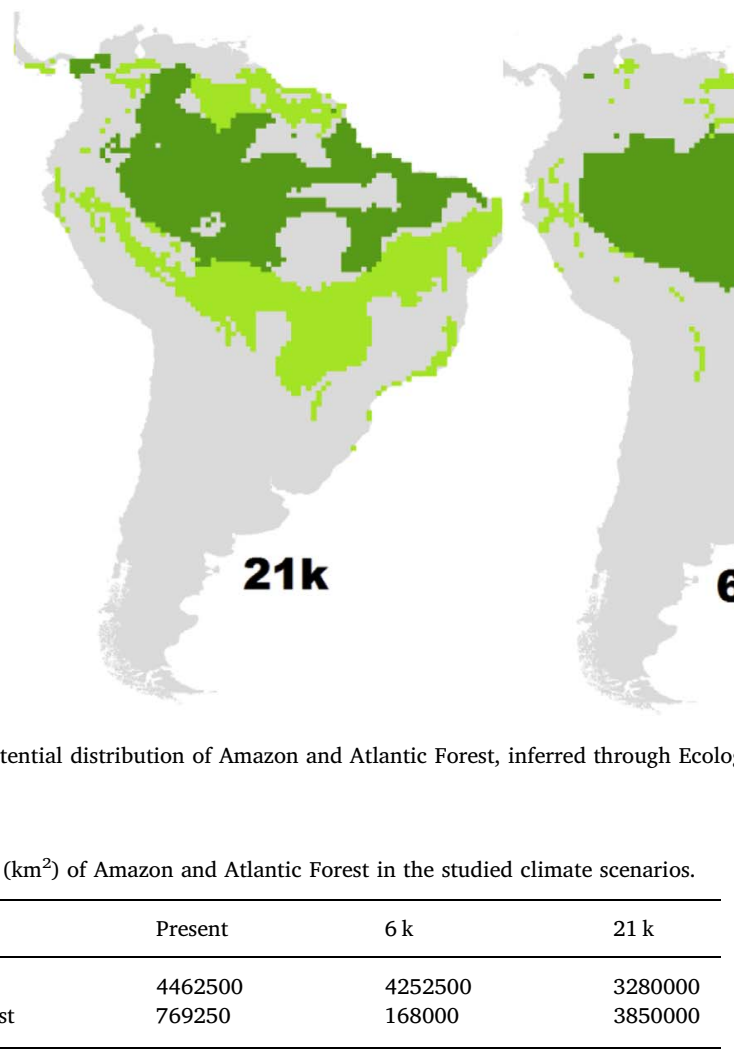

(Table 2). Comparison of the two biomes' values highlights the discrepancy in their PA efficiency with respect to CSA conservation.

\subsection{Areas for conservation prioritization}

We defined the following conservation prioritization for the Amazon biome: Very high priority areas are CSA localities with intact forest remnants and are geographically close to existing PAs, mainly in the biome's eastern region. High priority areas are CSAs composed of fragmented forest remnants and are located in the western Amazon region, with discontinuous and isolated PAs. Finally, medium priority areas are more recent CSAs (6ka to current), located in the central/ western Amazon region; these CSAs contain intact forest remnants and are considered vital for linking some very high priority areas with existed PAs (Fig. 4).

In the Atlantic Forest, the scenario is catastrophic. No very high priority areas were identified in the biome because intact forest is nonexistent in this area. The main Atlantic Forest CSAs are small, fragmented forest remnants and were therefore categorized as high priority areas (Fig. 4).

\section{Discussion}

The Atlantic Forest CSAs have a disjunct distribution in three different regions - north, center and south - while the Amazon CSAs are geographically continuous, mainly in the eastern region of the biome (Fig. 3). Using different methodologies, Carnaval and Moritz (2008), Carnaval et al. (2009), Batalha-Filho et al. (2013) and Carvalho and Del Lama (2015) identified CSAs in regions similar to those we predicted. However, the determination of Amazon CSAs is controversial, because studies of distinct taxa-such as butterfly, frog, lizard, bird and tree families-demarcate different CSAs (see Bush and Oliveira, 2006). Others question the veracity of Amazon CSAs because some of the studies did not used paleoclimatic data or evolutionary studies (Colinvaux et al., 2000; Bush and Oliveira, 2006), which may invalidate the current models of Amazon CSAs.

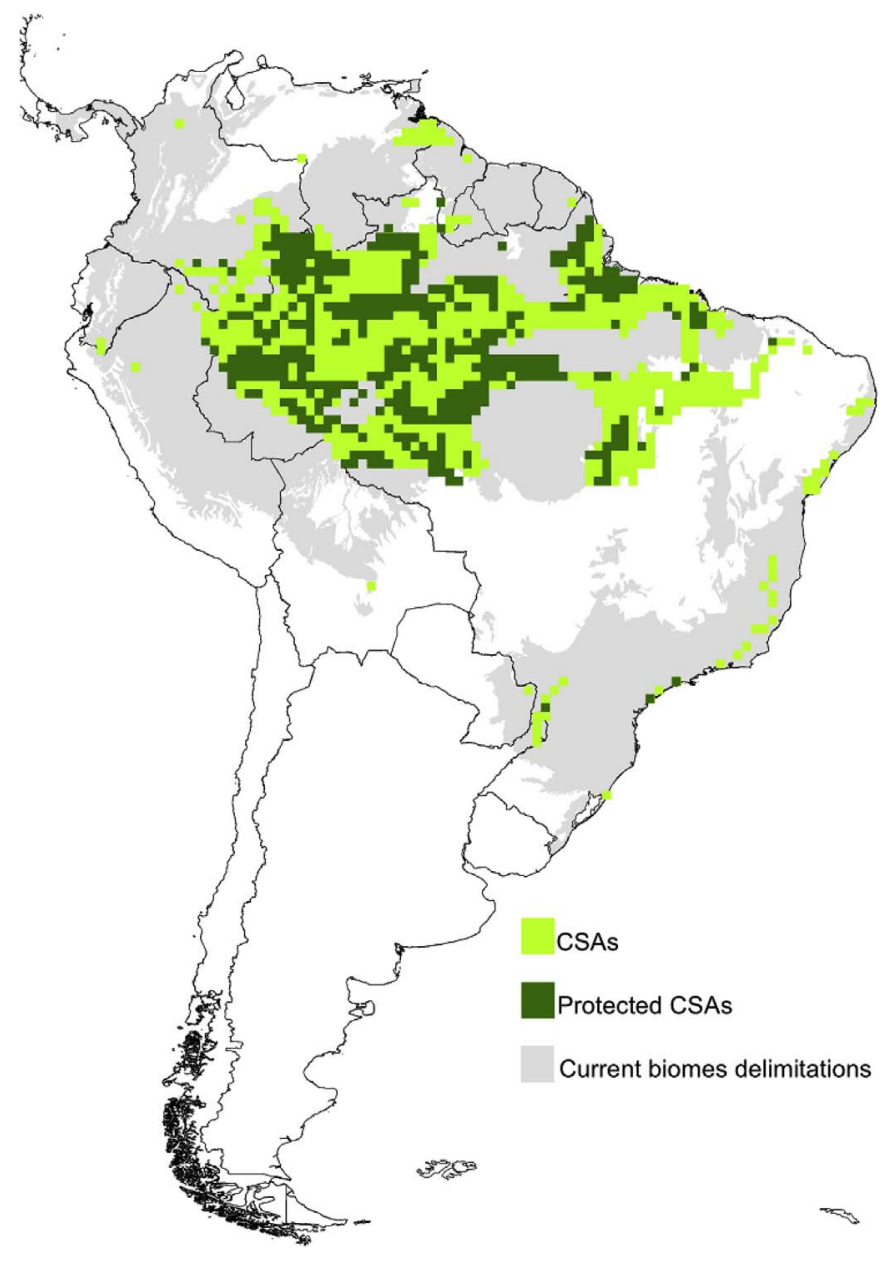

Fig. 3. Climatically stable areas (CSAs) of Amazon and Atlantic Forest and the protected climatically stable areas.

Although CSAs are recognized as priority conservation areas (Carnaval and Moritz, 2008; Keppel et al., 2015), no study has tested PA efficiency for Atlantic Forest and Amazon CSAs conservation. We found Amazon PAs to be more efficient than Atlantic Forest $(59.2 \%$ and $17.9 \%$ respectively; Table 2), perhaps because of the conservation history of each biome. According to Joly (personal communication) and 
Table 2

Predicted area, percentage of protection, climate stable area index, and efficiency index of Amazon and Atlantic Forest PAs.

\begin{tabular}{lll}
\hline & Amazon & Atlantic Forest \\
\hline Current Predicted Area $\left(\mathrm{km}^{2}\right)$ & 4462500 & 769250 \\
Protected Area $\left(\mathrm{km}^{2}\right)$ & 1787500 & 7000 \\
Climatically stable area $\left(\mathrm{km}^{2}\right)$ & 2597500 & 175000 \\
Protected Stable Area $\left(\mathrm{km}^{2}\right)$ & 1057500 & 12500 \\
Protection index $(\%)$ & 40.1 & 9.1 \\
CSA index (\%) & 58.2 & 22.7 \\
CSA protection index (\%) & 40.7 & 7.1 \\
Efficiency Index (\%) & 59.2 & 17.9 \\
\hline
\end{tabular}

Dean (1996), the Atlantic Forest PA network was created under a high forest fragmentation scenario, and most of the remaining forest was transformed into conservation units, independent of evolutionary history or ecological attributes. In contrast, the Amazon PA network was developed under a scenario of large, continuous forest patches and involved much debate about refuge and areas with high taxa diversity.

The lower efficiency of Atlantic Forest PAs for CSA conservation is reported here for the first time. This finding is corroborated by studies of PA efficiency in maintaining species richness under a climate change scenario: Lemes et al. (2014) showed decreasing richness of anurans in Atlantic Forest PAs under a global warming scenario. Loyola et al. (2014) inferred the reduction of phylogenetic diversity within Atlantic Forest PAs. Ferro et al. (2014) warned about a decreasing trend for moth species within Atlantic Forest PAs under a future climate scenario. All these findings point to a likely catastrophic scenario for the Atlantic Forest and highlight the low efficiency of Atlantic Forest PAs in preserving local biodiversity.

We found that only $18 \%$ of Atlantic Forest PAs overlap with CSAs, but this index no-included Argentina CSAs and PAs in the Misiones province. Even if we considered the Misiones CSAs the results evidence, coupled with inefficiency of Atlantic Forest PAs in conserving different taxa under climate warming (Lemes et al., 2014; Ferro et al., 2014; Loyola et al., 2014) and the negative influence of future climate shift on Atlantic Forest species distribution (Colombo and Joly, 2010), is cause for concern regarding the conservation of the Atlantic Forest in the coming years. Additionally, the increasing future extinction risk for threatened species (Sobral-Souza et al., 2015b) and the catastrophic landscape modification scenario (Ribeiro et al., 2009) reinforce the need for new conservation strategies to improve Atlantic Forest conservation. However, expand the current knowledge of the relationship between biodiversity, ecological processes and ecosystem services in different climate change scenarios are also important paramount in decision-making, since a highly fragmented landscape increases the complexity of conservation strategies (Joly et al., 2014).

Until now, no studies have tested the efficiency of the Amazon PA network for CSA conservation, and few articles reported on the PA network's efficiency in Amazonian species conservation. Studies in the Amazon suggest an intermediate (approximately 40\%) PA efficiency in the conservation of Amazonian mammals and freshwater chelonian species (Avezedo-Ramos et al., 2006; Fagundes et al., 2016). Simulations of future forest loss by Soares-Filho et al. (2006) confirmed that PAs are the principal conservation strategies adopted in the Amazon. While this strategy is important for biodiversity maintenance, PAs alone are insufficient as a conservation plan. According to the authors, increasing the area of current PAs and the creation of new PAs in private areas are measures that should be adopted, being the most efficient ways to conserve Amazonian biodiversity.

We proposed conservation priority areas for Amazon and Atlantic Forest biomes. Our results showed conflicting scenarios for the two Neotropical rainforests. We indicated three classes for Amazon

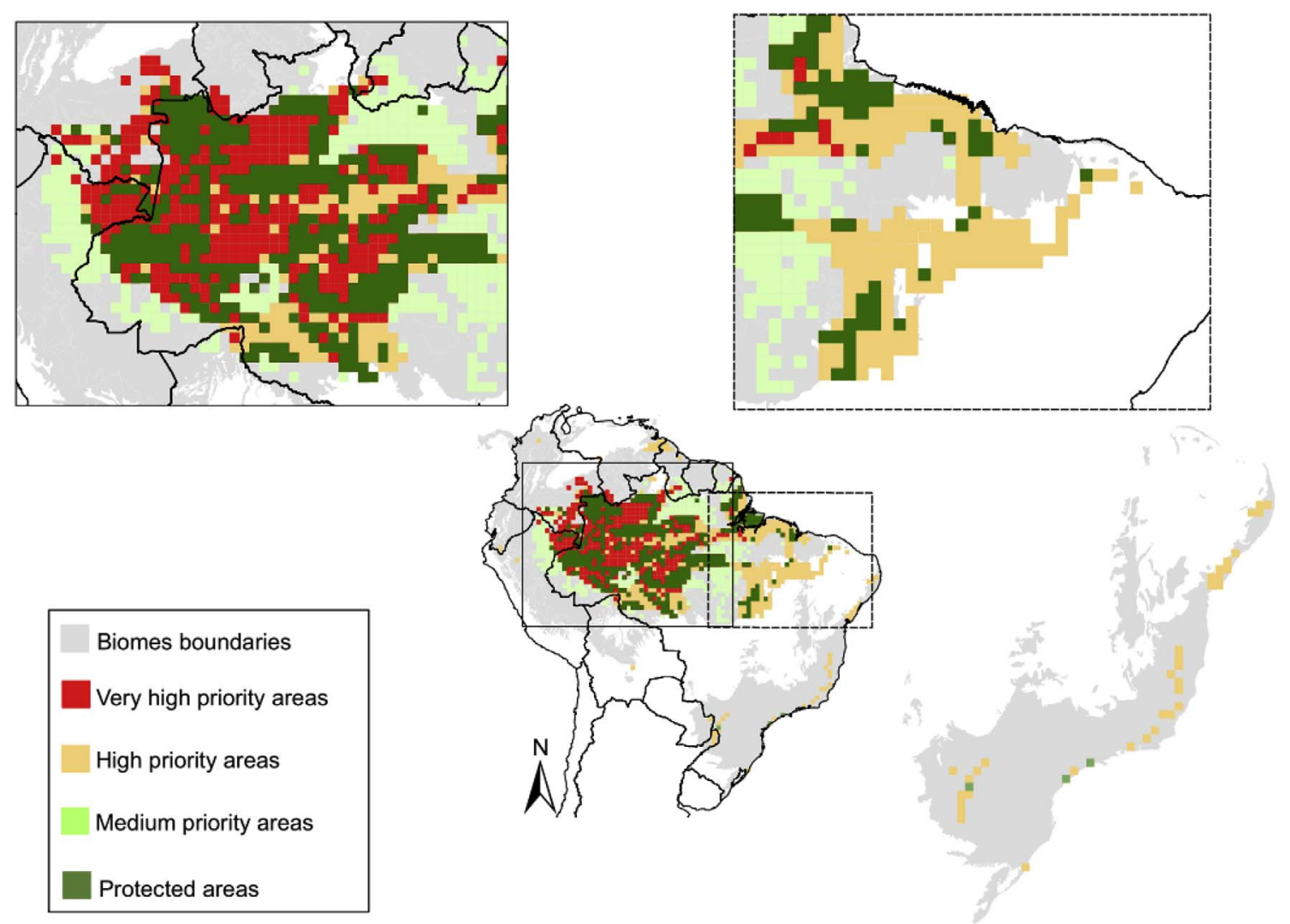

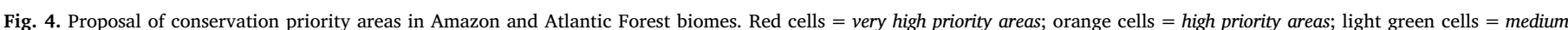

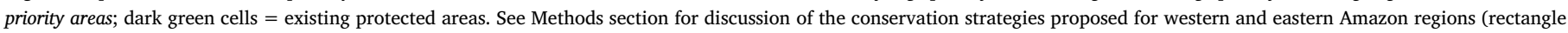
above) and Atlantic Forest (right below). (For interpretation of the references to colour in this figure legend, the reader is referred to the Web version of this article.) 
conservation (very high priority areas, high priority areas and medium priority areas) and only one (high priority areas) for Atlantic Forest (Fig. 4). Each type of conservation area that we propose requires a different conservation strategy. The very high priority areas (Fig. 4, shown in red) are intact CSA forests close to existing PAs in western Amazon. Their geographic proximity to PAs suggests that the creation of new PAs, or an increase in area of existing ones, that incorporate these high priority areas may be effective conservation strategies. The high priority areas (Fig. 4, shown in orange) are fragmented CSA forests and are therefore in need of restoration. The important priority areas of the western Amazon are near to existing PAs or intact fragments. The high resilience of these areas, due to seed banks and dispersion drivers, is an important precondition for high conservation effectiveness. In the eastern Amazon, however, resilience is low because agriculture and livestock are the predominant land uses in this region (Morton et al., 2006; DeFries et al., 2008), and because forested areas are distant. Consequently, sustainable replanting plans (to modify the agriculture system and land use) are necessary to increase PA efficiency in this region.

For Atlantic Forest the situation is dire because only a few forest remnants are large in size (e.g. > 10,000 ha; Ribeiro et al., 2009), and many of the remnants occur in areas with low climate stability. Even so, these Atlantic Forest CSA are localized on areas with high resilience and indicated as bottleneck of connectivity by Tambosi et al. (2014). These areas cover mainly the coastal zone of Atlantic Forest biome at Pernambuco, Bahia and Serra do Mar subregions, but also in the seasonal forests on the surroundings of Iguaçu State Park (Ribeiro et al., 2011).

Here, we demonstrated that Amazon PAs are more efficient than the Atlantic Forest PA network for CSA conservation. Our findings are similar to other studies that used different methods. We used a simple methodological framework that can easily be used in other biomes around the world to further an understanding of current PA efficiency based on the biomes' evolutionary climate histories. Decisions regarding new global conservation plans and PA network should use a variety of criteria based on prior knowledge of species richness, climatically stable areas, endemism zones, deforestation and carbon stock, among others, underscoring the need for new studies at local and global scales.

\section{Acknowledgments}

The authors thank Levi Carina Terribile for reviewing the manuscript and Luiz Filipe de Macedo Bartoleti and Megan F. King for english review. We thanks Rosane Collevatti by support fellowship Procad/ CAPES project \# 88881.068425/2014-01. TSS thanks CNPq (process 150319/2017-7) by postdoc fellow and Universidade Metropolitana de Santos, Unimes, by logistic and financial support. MHV thanks the support CAPES scholarship. MCR thanks CNPq for the research grant (312045/2013-1; 312292/2016-3), and FAPESP (process 2013/504212) for their financial support. MSLR thanks CNPq by financial grants (process 447426/2014-1).

\section{References}

Allouche, O., Tsoar, A., Kadmon, R., 2006. Assessing the accuracy of species distribution models: prevalence, kappa and the true skill statistic (TSS). J. Appl. Ecol. 43, 1223-1232.

Araújo, M.B., New, M., 2007. Ensemble forecasting of species distributions. Trends Ecol. Evol. 22, 42-47.

Araújo, M.B., Alagador, D., Cabeza, M., Nogués-Bravo, D., Thuiller, W., 2011. Climate change threatens European conservation areas. Ecol. Lett. 14, 484-492.

Araújo, M.B., Cabeza, M., Thuiller, W., Hannah, L., Williams, P.H., 2004. Would climate change drive species out of reserves? An assessment of existing reserve-selection methods. Global Change Biol. 10, 1618-1626.

Araújo, M.B., Williams, P.H., Fuller, R.J., 2002. Dynamics of extinction and the selection of nature reserves. Proc. Roy. Soc. Lond. B 269, 1971-1980.

Avezedo-Ramos, C., Amaral, B.D., Nepstad, D., Filho, B.S., Nasi, R., 2006. Integrating ecosystem management, protected area, and mammal conservation in Brazilian Amazon. Ecol. Soc. 11, 17.
Barry, S., Elith, J., 2006. Error and uncertainty in habitat models. J. Appl. Ecol. 43, 413-423.

Barve, N., Barve, V., Jiménez-Valverdade, A., Lira-Noriega, A., Maher, S.P., Peterson, A.T., Soberón, J., Villalobos, F., 2011. The crucial role of the accessible area in ecological niche modeling and species distribution modeling. Ecol. Model. 222, 1810-1819.

Batalha-Filho, H., Fjeldsa, J., Fabre, P.H., Myiaki, C.Y., 2013. Connections between the Atlantic and the Amazonian forest avifaunas represent distinct historical events. J. Ornithol. 154, 41-50.

Bellard, C., Bertelsmeier, C., Leadley, P., Thuiller, W., Courchamp, F., 2012. Impacts of climate change on the future of biodiversity. Ecol. Lett. 15, 365-377.

Bellard, C., Leclerc, C., Leroy-Bakkenes, M., Veloz, S., Thuiller, W., Courchamp, F., 2014 Vulnerability of biodiversity hotspots to global change. Global Ecol. Biogeogr. 23, 1376-1386.

Brown Jr., K.S., 1987. Biogeography and evolution of neotropical butterflies. In: Whitmore, T.C., Prance, G.T. (Eds.), Biogeography and Quaternary History in Tropical America. England, Oxford, pp. 66-104.

Bush, M.B., Oliveira, P.E., 2006. The rise and fall of the Refugial Hypothesis of Amazonian speciation: a paleoecological perspective. Biota Neotropica 6.

Cabeza, M., Moilanen, A., 2001. Design of reserve networks and the persistence of biodiversity. Trends Ecol. Evol. 16, 242-247.

Cabeza, M., Araujo, M.B., Wilson, R.J., Thomas, C.D., Cowley, M.J.R., Moilanen, A., 2004 Combining probabilities of occurrence with spatial reserve design. J. Appl. Ecol. 41, $252-262$.

Cabeza, M., 2003. Habitat loss and connectivity of reserve networks in probability approaches to reserve design. Ecol. Lett. 6, 665-672.

Carnaval, A.C., Moritz, C., 2008. Historical climate modelling predicts patterns of current biodiversity in the Brazilian Atlantic forest. J. Biogeogr. 351, 1187-1201.

Carnaval, A.C., Hickerson, M.J., Haddad, C.F.B., Rodrigues, M.T., Moritz, C., 2009. Stability predicts genetics diversity in the brazilian Atlantic forest hotspot. Science $323,785-789$.

Carpenter, G., Gillison, N.A., Winter, J., 1993. DOMAIN: a flexible modeling procedure for mapping potential distributions of animals and plants. Biodivers. Conserv. 2, 667-680.

Carvalho, A.F., Del-Lama, M.A., 2015. Predicting priority areas for conservation from historical climate modelling: stingless bees from Atlantic Forest hotspot as a case study. J. Insect Conserv. 19, 581-587.

Carvalho, C., Ballesteros-Mejia, L., Ribeiro, M.C., Côrtes, M.C., Santos, A.S., Collevatti, R.G., 2017. Climatic stability and contemporary human impacts affect the genetic diversity and conservation status of a tropical palm in the Atlantic Forest of Brazil. Conserv. Genet. 18, 467-478. http://dx.doi.org/10.1007/s10592-016-0921-7.

Clements, F.E., 1949. Dynamic Vegetation. The HW Wilson CO Press.

Colinvaux, P.A., De Oliveira, P.E., Bush, M.B., 2000. Amazonian and Neotropical plant communities on glacial time-scales: the failure of the aridity and refuge hypotheses. Quat. Sci. Rev. 19, 141-169.

Collevatti, R.G., Lima-Ribeiro, M.S., Diniz-Filho, J.A.F., Oliveira, G., Dobrovolski, R., Terribile, L.C., 2013. Stability of brazilian seasonally dry forests under climate change: inferences for long-term conservation. Am. J. Plant Sci. 4, 792-805.

Colombo, A.F., Joly, C.A., 2010. Brazilian Atlantic Forest lato sensu: the most ancient Brazilian forest, and a biodiversity hotspot, is highly threatened by climate change. Braz. J. Biol. 70, 697-708.

Colyvan, M., Burgman, M.A., Tood, C.R., Akçakaya, H.R., Boek, C., 1999. The treatment of uncertainty and the structure of the IUCN threatened species categories. Biol. Conserv. 89, 245-249.

Dean, W., 1996. With Broadax and Firebrand: the Destruction of the Brazilian Atlantic Forest. University of California Press, California.

DeFries, R.S., Morton, D.C., Van der Werf, G.R., Giglio, L., Collatz, G.J., Randerson, J.T., Houghton, R.A., Kasibhatla, P.K., Shimabukuro, Y., 2008. Fire-related carbon emissions from land use transitions in southern Amazonia. Geophys. Res. Lett. 35, 1-5.

Diniz-Filho, J.A.F., Bini, L.M., Rangel, T.F., Loyola, R.D., Hof, C., Nogués-Bravo, D., Araújo, M.B., 2009. Partitioning and mapping uncertainties in ensembles of forecasts of species turnover under climate change. Ecography 32, 897-906.

Dryflor, 2016. Plant diversity patterns and their conservation implications in neotropical dry forests. Science 353, 1383-1387.

Eldredge, N., Thompson, J.N., Brekefield, P.M., Gavrilets, S., Jablonski, D., Jackson, J.B.C., Lenski, R.E., Lieberman, B.S., McPeek, M.A., Miller III, W., 2005. The dynamics of evolutionary stasis. Paleobiology 31, 133-154.

Fagundes, C.K., Vogt, R.C., De Marco Jr., P., 2016. Testing the efficiency of protected areas in the Amazon for conserving freshwater turtles. Divers. Distrib. 22, 123-135.

Farber, O., Kadmon, R., 2003. Assessment of alternative approaches for bioclimatic modeling with special emphasis on the Mahalanobis distance. Ecol. Model. 160 115-130.

Fearnside, P.M., 1999. Biodiversity as an environmental service in Brazil's Amazonian forests: risks, value and conservation. Environ. Conserv. 26, 305-321.

Ferro, V.G., Lemes, P., Melo, A.S., Loyola, R.D., 2014. The reduced effectiveness of protected areas under climate change threatens Atlantic Forest tiger moths. PLoS One 9, e107792. http://dx.doi.org/10.1371/journal.pone.0107792.

Franklin, J., 2009. Mapping Species Distributions: Spatial Inference and Predictions. Cambridge University Press, Cambridge.

Haffer, J., Prance, G.T., 2001. Climatic forcing of evolution in Amazonia during the Cenozoic: on the refuge theory of biotic differentiation. Amazoniana 16, 579-608.

Haffer, J., 1969. Speciation in Amazonian forest birds. Science 165, 131-137.

Hoorn, C., Wesselingh, F.P., Ter-Steege, H., et al., 2010. Amazonia through time: andean uplift, climate change, landscape evolution, and biodiversity. Science 330, 927-931.

Jenkins, C.N., Joppa, L., 2009. Expansion of the global terrestrial protected area system. Biol. Conserv. 142, 2166-2174. 
Joly, C.A., Metzger, J.P., Tabarelli, M., 2014. Experiences from the Brazilian Atlantic Forest: ecological findings and conservation initiatives. New Phytol. 2014. http://dx. doi.org/10.1111/nph.12989.

Keppel, G., Mokany, K., Wardell-Johnson, G.W., Phillips, B.L., Welbergen, J.A., Reside, A.E., 2015. The capacity of refugia for conservation planning under climate change. Frontier of Ecology andEnvironment 13, 106-112.

Laurance, W.F., Goosem, M., Laurance, S.G.W., 2009. Impact of roads and linear clearings on tropical forests. Trends Ecol. Evol. 24, 659-669.

Lemes, P., Melo, A.S., Loyola, R.D., 2014. Climate change threatens protected areas of the Atlantic Forest. Biodivers. Conserv. 23, 357-368.

Lima, F., et al., 2017. ATLANTIC-CAMTRAPS: a dataset of medium and large terrestrial mammal communities in the Atlantic Forest of South America. Ecology 98, 2979. http://dx.doi.org/10.1002/ecy.1998.

Lima-Ribeiro, M.S., Varela, S., González-Hernández, J., Oliveira, G., Diniz-Filho, J.A.F., Terribile, L.C., 2015. Ecoclimate: a database of climate data from multiple models for past, present, and future for macroecologists and biogeographers. Biodivers. Inf. 10, $1-21$.

Loyola, R.D., Lemes, P., Brum, F.T., Provete, D.B., Duarte, L.D.S., 2014. Clade-specific consequences of climate change to amphibians in Atlantic Forest protected area. Ecography 37, 65-72.

Loyola, R.D., Lemes, P., Faleiro, F.V., Trindade-Filho, J., Machado, R.B., 2012. Severe loss of suitable climatic conditions for marsupial species in Brazil: challenges and opportunities for conservation. PLoS One. http://dx.doi.org/10.1371/journal.pone. 0046257.

Margules, C.R., Pressey, R.L., 2000. Systematic conservation planning. Nature 405, 243-253.

Martinelli, G., Valente, A.S.M., Maurenza, D., et al., 2013. Avaliação de risco de extinção de espécies da flora brasileira. In: Martinelli, G., Moraes, M.A. (Eds.), Livro vermelho da flora do Brasil. CNC Flora, Jardim Botânico do Rio de Janeiro, Rio de Janeiro, pp. $60-84$.

Mittermeier, R.A., Robles, G.P., Hoffmann, M., Pilgrim, J., Brooks, T., Mittermeier, C.G., Lamorex, J., Fonseca, G.A.B., 2004. Hotspots Revisited. The Chicago University Press.

Morton, D.C., DeFries, R.S., Shimabukuro, Y.E., Anderson, L.O., Arai, E., Espirito-Santo, F.B., Freitas, R., Morisette, J., 2006. Cropland expansion changes deforestation dynamics in the southern Brazilian Amazon. Proc. Natl. Acad. Sci. Unit. States Am. 103, 14637-14641.

Myers, N., Mittermeier, R.A., Mittermeier, C.G., Fonseca, G.A.B., Kent, J., 2000. Biodiversity hotpots for conservation priorities. Nature 403, 853-858.

Nix, H., 1986. A biogeographic analysis of Australian Elapid snakes. In: Longmore, R. (Ed.), Snakes: Atlas of Elapid Snakes of Australia. Bureau of Flora and Fauna, pp. 4-10.

Olson, D.M., Dinerstein, E., Wikramanayake, E.D., et al., 2001. Terrestrial ecoregions of the world: a new map of life on Earth. Bioscience 51, 933-938.

Onal, H., Briers, R.A., 2002. Incorporating spatial criteria in optimum reserve network selection. Proc. Roy. Soc. Lond. B 269 (1508), 2437-2441.
Pearson, R.G., Raxworthy, C.J., Nakamura, M., Peterson, A.T., 2007. Predicting species distributions from small numbers of occurrence records: a test case using cryptic geckos in Madagascar. J. Biogeogr. 34, 102-117.

Peterson, A.T., Soberón, J., Pearson, R.G., Anderson, R.P., Martínez-Meyer, E., Nakamura, M., Araújo, M.B., 2011. Ecological Niches and Geographic Distributions. Princeton University Press, Princeton.

Phillips, S.J., Dudik, M., 2008. Modeling of species distributions with Maxent: new extensions and a comprehensive evaluation. Ecography 31, 161-175.

Prado, D.E., 2000. Seasonally dry forests of tropical south America: from forgotten ecosystems to a new phytogeographic unit. Edinb. J. Bot. 57, 437-461.

Prance, G.T., 1982. Biological Diversity in the Tropics. Columbia University Press, New York.

Ribeiro, M.C., Metzger, J.P., Martensen, A.C., Ponzoni, F.J., Hirota, M.M., 2009. The Brazilian Atlantic Forest: how much is left, and how is the remaining forest distributed? Implications for conservation. Biol. Conserv. 142, 1141-1153.

Ribeiro, M.C., Martensen, A.C., Metzger, J.P., Tabarelli, M., Scarano, F., Fortin, M.-J., 2011. The Brazilian Atlantic Forest: a shrinking biodiversity hotspot. In: Zachos, F.E. Habel, J.C. (Eds.), Biodiversity Hotspots. Springer, pp. 405-434.

Root, T.L., Price, J.T., Hall, K.R., Schneider, S.H., Rosenzweig, C., Pounds, A., 2003. Fingerprints of global warming on wild animals and plants. Nature 421, 57-60.

Rylands, A.B., Brandon, K., 2005. Brazilian protected areas. Conserv. Biol. 19, 612-618.

Salati, E., Vose, P.B., 1984. Amazon basin: a system in equilibrium. Science 225, 129-138.

Scarano, F.R., Ceotto, P., 2015. Brazilian Atlantic Forest: impact, vulnerability and adaptation to climate change. Biodivers. Conserv. 24, 2319-2331.

Soares-Filho, B.S., Nepstad, D.C., Curran, L.M., Cerqueira, G.C., Garcia, R.A., Ramos, C.A., Voll, E., McDonald, A., Lefebvre, P., Schlesinger, P., 2006. Modelling conservation in Amazon basin. Nat. Latt. 440 (7083), 520-523.

Sobral-Souza, T., Lima-Ribeiro, M.S., Solferini, V.N., 2015a. Biogeography of Neotropical Rainforests: past connections between Amazon and Atlantic Forest detected by ecological niche modeling. Evol. Ecol. 29, 643-655.

Sobral-Souza, T., Francini, R.B., Lima-Ribeiro, M.S., 2015b. Species extinction risk might increase out of reserves: allowances for conservation of threatened butterfly Actinote quadra (Lepidoptera: Nymphalidae) under global warming. Nat. Conserv. 13, 159-165.

Tambosi, L.R., Martensen, A.C., Ribeiro, M.C., Metzger, J.P., 2014. A framework to optimize biodiversity restoration efforts based on habitat amount and landscape connectivity. Restor. Ecol. 22, 169-177.

Tax, D.M.J., Duin, R.P.W., 2004. Support vector data description. Mach. Learn. 54, 45-66.

Terribile, L.C., Lima-Ribeiro, M.S., Araújo, M.B., et al., 2012. Areas of climate stability of species ranges in the brazilian Cerrado: disentangling uncertainties through time. Nat. Conserv. 10, 152-159.

Vanzolini, P.E., Williams, E.F., 1981. The vanishing refuge: a mechanism for ecogeographic speciation. Papéis Avulsos do Museus de Zoologia 34, 251-255.

Whittaker, R.H., 1971. Communities and Ecosystems. Frinting. The Macmillan Co. Press. 